\title{
SOCIAL MEDIA INFLUENCER, BRAND AWARENESS, AND PURCHASE DECISION AMONG GENERATION Z IN SURABAYA
}

\author{
Leonardo Gunawan ${ }^{1}$, Selden Haryono ${ }^{2}$, Fransisca Andreani ${ }^{3 *}$ \\ ${ }^{123}$ Faculty of Business and Economics, Petra Christian University \\ Email: ${ }^{1}$ gunawanleo98@gmail.com, ${ }^{2}$ seldenharyono@gmail.com, ${ }^{3}$ andrea@ petra.ac.id \\ *Corresponding author
}

\begin{abstract}
Many restaurants and cafes used Social Media Influencer (SMI) services to promote their products/ services. The three dimensions of SMI included reach, relevance, and resonance; and these can influence brand awareness and purchase decision of Generation Z consumers. This study involved 108 respondents and used SPSS and Partial Least Square (PLS) as software programs to analyze data using multivariate analysis. The results of this study indicated that reach, relevance and resonance of SMI had positive and significant influences on brand awareness. Reach had positive but insignificant influence on purchase decisions; whereas, relevance and resonance had positive and significant influences on purchase decision. Finally, brand awareness had positive but insignificant influence on purchase decision of Generation $\mathrm{Z}$ to restaurants and cafes in Surabaya.
\end{abstract}

Keywords: Social media influencer (SMI), instagram, brand awareness, purchase decision, generation z

\section{Introduction}

Nowdays many companies use electronic communication media as a media of promoting products or services, corporate value, or even strengthening company brand awareness. In modern time, the development of communication media has led to the emergence of human idol icons who consumers often refer to as celebrities; this is an opportunity for entrepreneurs in Indonesia to utilize Social Media Influencers (SMIs) to become endorsers of company-owned products (Devi, 2018). Companies make use of endorsers or celebrities and famous people as influencers. These terms actually refer to the same thing: endorsers or celebrities or influencers who provide product or service reviews on social media.

Companies are competing to use various marketing techniques to win their consumers. Among those tools, a Social Media Influencer (SMI) has become one of the most effective ways for promoting corporate brands. According to Glucksman (2017), the use of SMI became the largest marketing and public relations tool in 2017. Inevitably, the role of SMI and personal identities possessed have become the main features of communication media and continued to grow for a long time. The definition of Social Media Influencers itself according to Hariyanti and Wirapraja (2018, p. 141) refers to figures on social media, who have a large number of followers and can influence the followers' behavior. Influencer figures can come from various professions, starting from artists, celebrities, bloggers, figures, and so on.

Social Media Influencer is one of the newest form of celebrities in cyberspace. This is a form of postmodernism in celebrity cyberspace without having the skills as an artist, businessman, or politician. Social Media Influencer (SMI) has a tendency as a famous person who can influence many people. SMI represents a new type of an independent party influencer who affects the attitudes of potential consumers through blogs, tweets, Instagram, and the use of other people's social media. Although there are some researchers who view SMI as very competitive with each other just to master social media (Gorry \& Westbrook, 2009), other SMIs recognize the emergence of opportunities in working with companies in promoting brand products/ services marketed by companies. This trend is the basis for company leaders to use SMI as a promotional medium for companies to increase brand awareness and sales.

The impact that is often desired from a company is a high brand awareness by using Social Media Influencer's service. Brand awareness is the ability of consumers to recognize and remember a brand in different situations (Yang, Chi, \& Yeh, 2009). According to previous research conducted by Owyang, Jones, Tran, and Nguyen (2011), influencers have an appeal to brand awareness and buying interest for consumers. In addition, brand awareness can also have a significant impact on purchase decisions as well (Lukman, 2014). Purchase decision alone can be interpreted as determining the choice from two or more alternatives to meet consumer needs (Peter \& Olson, 2014, p. 163). Brand awareness, brand positioning, and purchase decisions are the impacts of making use of SMIs.

In previous studies, many scholars analyzed the objects of celebrity influencers. Studies by Royan (2004), Sharon, Meilinda, Wijaya, and Iskandar (2018), Sampurno, Ciakrawinata, and Jokom (2019) employ four dimensions of communication 
characteristics delivered through the VisCap model (Visibility, Credibility, Attraction, and Power). These characteristics were developed from Rossiter, Percy, and Berkvist (2018). What distinguishes this research from the previous ones is the chosen influencer. This research uses SMI objects and different dimensions and indicators from how to assess the performance of a celebrity influencer. The similarity is that this study is focused to see the effect of the characteristics of celebrity influencers on purchase intention, even though preferences and purchase intention do not always produce actual purchase decision (Habibi, 2014). Therefore, the researchers want to see the effects of SMIs on purchase decision and brand awareness.

The dimensions of SMI used in this research refer to the ones proposed by Solis and Webber (2012). These can be categorized as Reach, Resonance, and Relevance. Reach, refers to numbers of followers or followers who engage in social media, such as the ones who like, share, retweet, comment, click on the URL link, or fill in the form or purchase on posts made by influencers. Resonance, is an act of social media followers who continue or share more content from influencers. The more contents distributed by followers, the higher the SMI resonance. The last dimension is relevance. The meaning of relevance is the level of conformity or similarity between the values held by influencers and brand image of the products or services. Relevance can also mean whether influencers have similarities with consumers in the aspects of values, culture, and demographics of potential consumers of these products (Solis \& Webber, 2012).

The growing use of SMI is not only adapted by large-scale food and beverage companies. The restaurants and cafes also employ influencers to increase brand awareness, purchase intention, and other effects of the business. In Surabaya, the use of SMI services is arisen especially in new cafes among young people. The right use of SMI services can obtain a large market share while increasing indirect profits for the restaurants and cafes.

A lot of previous researches studied Generation $\mathrm{Y}$, but in this study, the researchers are interested in seeing the significance use of SMI on brand awareness and purchase decisions among Generation Z in Surabaya. Generation $Z$ is very intensive in using social media; one of which is Instagram as reported by Business Insider. Generation $\mathrm{Z}$ uses the most three social media platforms, namely Instagram, Snapchat, and YouTube. A different survey was also conducted by Business Insider in 2019 in which one of the top three trusted social media sites was Instagram, as the only visual and review-based media often used by SMIs.
From this phenomenon, Instagram becomes the main reference for Generation $\mathrm{Z}$ to find information about restaurants and cafes, especially Instagram users in Surabaya. This is the reason why business owners utilize Instagram as a medium to promote business (Suryani, 2015).

Generation $\mathrm{Z}$ have their own habits that influence their purchase behaviour. It is the impact of their lifestyle who like to gather with friends, hang out in cafes and restaurants, shop online, go for a trip, or even enjoy year-end leave (Renaldo, Sudarno, \& Marice, 2020). This is why Generation $Z$ often spend money more compared to Generation Y eventhough they are both social media savvy. Furthermore, Generation Z will be the highest potential market for cafes and restaurant business stakeholder.

Unfortunately, the use of SMI cannot be done haphazardly by the restaurant and cafe business owners. The impact of selecting SMI also varies depending on the dimensions the business owners wish to emphasize. Therefore, five most popular SMIs including Koko Buncit (@kokobuncit), Vicky Yuwono (@vickyyuwono), Amanda Kohar (@amandaakohar), Cece Kuliner (@cecekuliner), Inijie (@inijie), are chosen as they are more focused on endorsing culinary businesses in Surabaya.

The purpose of this study is to find out the impacts of SMIs on brand awareness and purchase decision among Generation Z in Surabaya. It is also hoped that SMIs can maximize their roles to endorse restaurants and cafes in Surabaya to increase brand awareness that may affect purchase decision of Generation $\mathrm{Z}$.

\section{Social Media Influencers (SMIs)}

The development of SMI theory is very broad, Rossiter et al. (2018) assessed SMI with visibility, credibility, attractiveness, and power (VISCAP) through widely used promotional media, including television, radio, newspaper magazines, etc. Then, Solis and Webber (2012) stated three dimensions of SMIs, which were reach, relevance, and resonance.

1. Reach is an ability of SMIs to reach communities on social media and how far their information can be disseminated into a community. This refers to how many followers or followers who have virtual contact with SMIs such as like, share, retweet, comment, click on the URL link, or fill out the form/ purchase on posts made by SMIs. There are three indicators of reach, namely:

a. Popularity is SMIs' state that is liked, admired, or supported by many people. This indicator is usually measured by the number of followers on social media. 
b. Proximity is the proximity of SMIs' location to social media users. People who have common location or community have a tendency to be close naturally due to the influence of environmental equality to language.

c. Goodwill refers to SMIs' special attention (in the form of hospitality, helping consumers find information, and the like) to social community that can increase social media users' appreciation.

2. Relevance is the glue between SMIs and social community. SMIs relate with individuals and social community based on social media users' points of interest. It can be measured through the similarity of SMIs' profiles with what consumers are looking for. This similaritiy includes values, culture, and demographics. The indicators of reach are:

a. Authority refers to SMIs' expertise on certain field so that naturally they become 'senior' over time in the related field. Thus, media users will appreciate, respect them more.

b. Trust is the most important aspect of the relationship. It is a belief in SMIs' reliability, honesty, ability, or strength.

c. Affinity is social media users' compassion to SMIs on the basis of similar interests. Consumers who are connected with SMIs build closeness in the social media community that strengthens the position of SMIs due to similarity of consumer preferences.

3. Resonance is the act of a social media followers who forward or redistribute endorsement from SMIs. As a result, more and more social media users see and read the endorsement. The more contents distributed by followers, SMIs' resonance will be greater. Three indicators that can assess the resonance are as follows:

a. Frequency is the numbers media users visit SMIs' profiles, contents, endorsements uploaded by SMIs.

b. Period is length of time SMIs' ads are viewed by media users after the first day the related content is uploaded on social media.

c. Amplitude is the number of people involved in social networks of SMIs' social media (engagement in Instagram). This is measured by the number of likes and comments via Instagram.

In his research, Guruge (2018) used Solis theory (2012) to analyze the attributes of SMIs. The strong point of the model proposed by Solis and Webber (2012) is the use of specific attributes refering to SMIs themselves and not to celebrity endorsers in broad terms. Specifically, the attributes are used only for social media and not used for mass media in general, like newspapers, television, etc. Engagement is also used to measure uploaded contents by SMIs which differentiate them from the existing models.

\section{Brand Awareness}

Brand awareness is the ability of consumers to recognize and remember a brand in different situations (Yang et al., 2009). Furthermore, Rangkuty (2004) explained the level of brand awareness experienced by consumers into four stages, namely unaware of the brand, brand recognition, brand recall, and top of mind. Shimp, Wood, and Smarandescu (2007, pp.38, 158) also put forward the same theory regarding brand awareness. Shimp et al. divided brand awareness into four stages, namely:

1. Unaware of Brand

This first level is the lowest level in the brand awareness pyramid, at which consumers are not aware of a brand at all.

2. Brand recognition

This is a minimum level of brand awareness. In this stage, a brand becomes important when consumers choose that brand in making a purchase.

3. Brand recall

This can occur when consumers are asked to mention the brand in a class of products and the consumer successfully mentions the expected brand. Consumers can recall the brand without the help of others.

4. Top of Mind.

At this level, among many other brands, there is only one to be remembered in the consumer minds. For example. if consumers are directly asked to name a brand without the assistance of others; then the consumers can mention the brand as expected. The brand most mentioned first by many consumers is the top of mind.

\section{Purchase Decision}

Purchase decision can be interpreted as a choice by consumers for two or more alternatives to meet their needs (Peter \& Olson, 2014, p.163). According to Kotler and Keller (2016), purchase decisions are included in the five stages by consumers in the process before and after purchase. Later on, Kotler and Keller (2016) proposed five empirical indicators in determining consumer purchase decisions, namely: 
1. Consumers have needs that can be met by companies.

2. Consumers gather information about the needs that can be met by companies.

3. Consumers choose companies over competitors.

4. Consumers decide to buy products provided by companies.

5. Consumers are satisfied after buying companies' products.

\section{SMI and Brand Awrareness}

Booth and Matic's research (2011) suggested that companies making use of SMI services into a company's social media strategy produce measurable, clear, and positive results on brand equity. Brand equity itself consists of several dimensions, one of which is brand awareness. This means that SMI influences the growth of brand awareness. Therefore, there is a significant relationship between SMI and brand awareness.

Marketing activities such as promotion using SMI services will affect consumers' perceptions about a brand (whether consumers are aware or not of the brand). Usually to get greater brand awareness, companies must be able to bind consumer emotions using marketing communication, adequate product values and attributes that are emotionally linked to consumers. One way to communicate can be through intermediaries who are often known as brand ambassadors to SMIs. The use of brand ambassadors and SMIs in HIJUP product research has been proven to signifycantly increase brand awareness of these products (Purwaningwulan, Suryana, Wahyudin, \& Dida, 2018)

Referring to the above explanation, the hypotheses in this study are:

$H_{I}$ : Reach aspect of SMI has a significant effect on brand awareness of restaurants and cafes toward Generation Z in Surabaya.

$\mathrm{H}_{2}$ : Relevance aspect of SMI has a significant effect on brand awareness of restaurants and cafes toward Generation Z in Surabaya.

$H_{3}$ : Resonance aspect of SMI has a significant effect on brand awareness of restaurants and cafes toward Generation Z in Surabaya.

\section{SMIs and Purchase Decision}

In a previous study by Sudha and Sheena (2017), it was found a significant influence of SMIs on consumer purchase decisions in the fashion industry in India. Therefore, companies focus more on promoting and advertising their products/ services through SMIs. Furthermore, Cooley and Parks-Yancy (2019) also found empirical evidence of the SMI influences on consumer purchase decisions in the fashion industry.

According to experts, SMI is a third party who significantly shapes consumer purchase decisions (Brown \& Hayes, 2008, pp. 49-50). In line with previous studies, Guruge (2018) also found SMI attributes that influence purchase decisions. The existing studies have strengthened the evidences of SMI's impacts on consumer purchase decisions. Based on this explanation, the next hypotheses are:

$H_{4}$ : Reach aspect of SMI has a significant effect on purchase decision of restaurants and cafes toward Generation Z in Surabaya.

$H_{5}$ : Relevance aspect of SMI has a significant effect on purchase decision of restaurants and cafes toward Generation Z in Surabaya.

$H_{6}$ : Resonance aspect of SMI has a significant effect on purchase decision of restaurants and cafes toward Generation Z in Surabaya.

\section{Brand Awareness and Purchase Decision}

A previous study conducted by Lukman (2014) found evidence that brand awareness has a significant influence on purchase decisions of Sosro tea beverage products in Bandung. Factors of brand equity, which are brand awareness and brand image, have shown to significantly influence consumer purchase decisions in the city.

In addition to this research, brand awareness is also proven to shape a purchase decision through brand perception (Kunto \& Agusli, 2013, p. 1). According to Soebianto (2014), brand equity also added to opportunities for consumers to decide to buy a product or service when consumers become selective in choosing the product/ service. Brand awareness indicates consumer positive response that may lead into consumer purchase decisions. The greater the brand awareness of a product/service, the greater the decisions of consumers to purchase the brand. Therefore, the next hypothesis is:

$H_{7}$ : Brand awareness has a significant effect on purchase decisions of restaurants and cafes toward Generation Z in Surabaya.

\section{Research Methods}

This is a quantitative causal research. A quantitative research emphasizes on the relationship between or among variables, testing theories, and looking for generalizations. It is directed to look at the existing 
phenomena and will be compared with existing theories (U Rianse, 2012).

The population of this research is Generation $\mathrm{Z}$ who have read the promotion or endorsements made by SMIs on Instagram and made purchases at the restaurants and cafés in Surabaya. Therefore, the population in this study is infinite. The sample in this study is the Generation $\mathrm{Z}$ with th e following criteria:

1. Respondents who have sufficient purchasing power and mature, aged of 17 to 25 years in April 2020 (bornt in 1995-2003)

2. Respondents who have ever read endorsements by SMIs on Instagram

3. Respondents who have ever made a purchase at restaurants and cafes promoted by five SMIs on Instagram

4. Respondents who have recognized one of the five SMIs in this study (whether or not they follow the social media of the SMIs).

Online questionnaires employ Likert scales from 1 (strongly disagree) to 5 (strongly agree). A total 121 questionnaires were distributed in this study, but 13 of them were not valid. So only 108 data can be analyzed with response rate of $89.26 \%$. Multivariate analysis is used to analyze the data with the help of Partial Least Square (PLS) software program.

The research model can be shown in Figure 1.

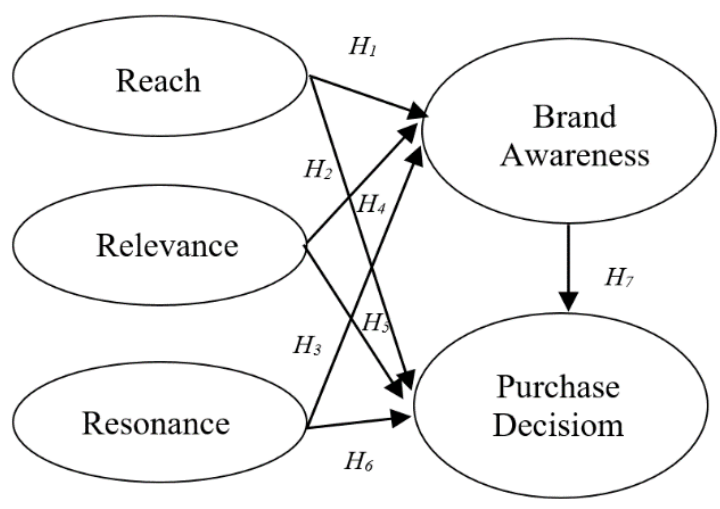

Figure 1. Research model

While the indicators of the variables are as per Table 1.

Table 1

The Indicators of Variables

\begin{tabular}{cl}
\hline Attributes & Indicators \\
\hline$X_{11}$ & $\begin{array}{l}\text { SMI is very popular in Instagram and has a } \\
\text { lot of followers. }\end{array}$ \\
$X_{12}$ & $\begin{array}{l}\text { SMI has social similarities with Generation Z } \\
\text { in languages and social environment. }\end{array}$ \\
$X_{13}$ & $\begin{array}{l}\text { SMI pays special attention to Generation Z by } \\
\text { sharing informations about cafes and restau- } \\
\text { rants. }\end{array}$
\end{tabular}

\begin{tabular}{|c|c|}
\hline Attributes & Indicators \\
\hline$X_{21}$ & $\begin{array}{l}\text { SMI has specialization and competencies in } \\
\text { endorsing cafes and restaurants. }\end{array}$ \\
\hline$X_{22}$ & $\begin{array}{l}\text { SMI can be trusted while promoting and } \\
\text { endorsing products or service in cafes and } \\
\text { restaurants. }\end{array}$ \\
\hline$X_{23}$ & $\begin{array}{l}\text { SMI has similar interest with Generation } \mathrm{Z} \text { in } \\
\text { cafes and restaurants. }\end{array}$ \\
\hline$X_{31}$ & $\begin{array}{l}\text { SMI makes Generation } \mathrm{Z} \text { read and observe } \\
\text { SMI's endorsement frequently. }\end{array}$ \\
\hline$X_{32}$ & $\begin{array}{l}\text { Endorsements from SMI could last for a long } \\
\text { time starting from the first endorsement was } \\
\text { published. }\end{array}$ \\
\hline$X_{33}$ & $\begin{array}{l}\text { Endorsements from SMI in Instagram get a } \\
\text { huge amounts of likes and comments. }\end{array}$ \\
\hline$X_{34}$ & $\begin{array}{l}\text { Endorsements from SMI are reshared or } \\
\text { forwarded by Generation Z in Instagram. }\end{array}$ \\
\hline$Y_{11}$ & $\begin{array}{l}\text { Generation } Z \text { can be aware of the brands of } \\
\text { the cafes and restaurants. }\end{array}$ \\
\hline$Y_{12}$ & $\begin{array}{l}\text { Generation } \mathrm{Z} \text { can recognize the brands of the } \\
\text { cafes and restaurants reviewed by SMI. }\end{array}$ \\
\hline$Y_{13}$ & $\begin{array}{l}\text { Generation } \mathrm{Z} \text { can remember the brands of the } \\
\text { cafes and restaurants reviewed by SMI. }\end{array}$ \\
\hline$Y_{14}$ & $\begin{array}{l}\text { Generation } \mathrm{Z} \text { can mention firstly the brands } \\
\text { of the cafes and restaurants reviewed by SMI } \\
\text { in Instagram. }\end{array}$ \\
\hline$Y_{21}$ & $\begin{array}{l}\text { Generation } \mathrm{Z} \text { has needs that can be fulfilled } \\
\text { by cafes and restaurants in Surabaya. }\end{array}$ \\
\hline$Y_{22}$ & $\begin{array}{l}\text { Generation } \mathrm{Z} \text { seeks informations about cafes } \\
\text { and restaurants promoted by SMI in Ins- } \\
\text { tagram. }\end{array}$ \\
\hline$Y_{23}$ & $\begin{array}{l}\text { Generation } \mathrm{Z} \text { prefers to choose cafes and } \\
\text { restaurants promoted by SMI compared to } \\
\text { similar competitors. }\end{array}$ \\
\hline$Y_{24}$ & $\begin{array}{l}\text { Generation } \mathrm{Z} \text { decides to buy products or } \\
\text { service provided by cafes and restaurants in } \\
\text { Surabaya promoted by SMI. }\end{array}$ \\
\hline$Y_{25}$ & $\begin{array}{l}\text { Generation } \mathrm{Z} \text { feels satisfied after purchasing } \\
\text { cafes or restaurants' products in Surabaya } \\
\text { promoted by SMI. }\end{array}$ \\
\hline
\end{tabular}

\section{Results and Discussion}

\section{Results}

The respondents in this research are mostly woman $(62.04 \%)$ and students (87.03\%). In addition, the respondents have allowances under $\mathrm{Rp} 2,000,000.00$ (50.93\%). Most of them recognized SMI of Koko Buncit (28.96\%) and spent one to three hours a day (51.85\%) and also bought main courses (38.95\%) as one of the most frequent dishes that Generation $\mathrm{Z}$ purchase.

The descriptive analysis also shows that means of the five variables (mean of reach 4.15, relevan 4.09, relevance 3.88 , brand awareness 4.08 and purchase decision 4.07) are high. These mean that SMIs have been performing well in their own social media, Instagram. 
Furthermore, the results of convergent validity show that all indicators have outer loadings greater than 0.50 and only the first indicator of reach that is not valid as its value of outer loading is 0.42 . So, this indicator is not used for further analysis. Then, the values of AVE from five variables (reach 0.75, relevance 0.54 , resonance 0.55 , brand awareness 0.56 and purchase decision 0.51 ) are bigger than 0.50 . So, all variables are valid.

Table 2

Composite Reliability and Cronbach's Alpha

\begin{tabular}{lcc}
\hline Variabel & $\begin{array}{c}\text { Composite } \\
\text { Reliability }\end{array}$ & $\begin{array}{c}\text { Cronbach's } \\
\text { Alpha }\end{array}$ \\
\hline Reach & 0.85 & 0.66 \\
Relevance & 0.78 & 0.60 \\
Resonance & 0.83 & 0.73 \\
Brand awareness & 0.83 & 0.73 \\
Purchase decision & 0.83 & 0.73 \\
\hline
\end{tabular}

Table 2 indicates the values of composite reliability (reach 0.85 , relevance 0.78 , resonance 0.83 , brand awareness 0.83 , and purchase decision 0.83 ) and the value of Cronbach's Alpha (reach 0.66, relevance 0.60 , resonance 0.73 , brand awareness 0.73 , and purchase decision 0.75 ) are bigger than 0.60 . Thus, all five variables are reliable.

In addition, the results of inner model can be seen from Figure 2.

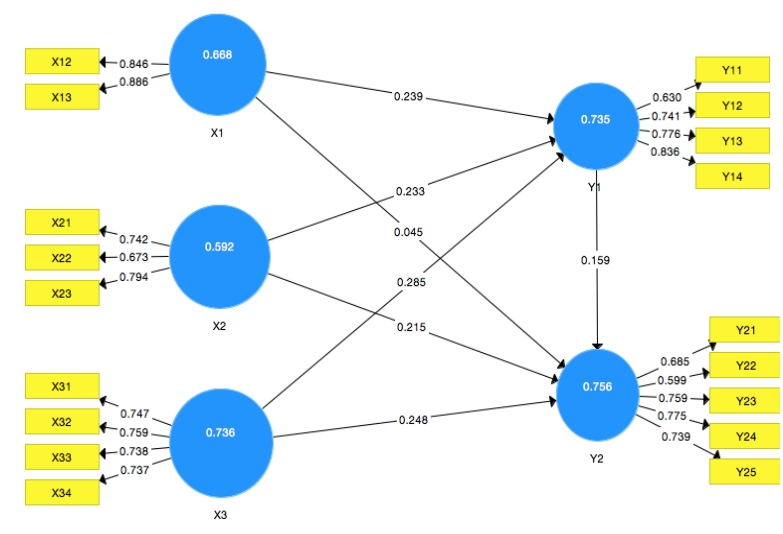

Figure 2. Inner model

The results of $R^{2}$ indicate that SMIs dimensions of reach, relevance and resonance have influenced brand awareness as much as $33 \%$. While, the influence of SMIs dimensions on purchase intention is as much as $27 \%$.

Apart from that, the results of PLS-SEM analysis are as per Table 3 . Table 3 indicates that five $\left(H_{1}, H_{2}\right.$, $H_{3}, H_{5}$, and $H_{6}$ ) of seven hypotheses are supported and the other two hypotheses $\left(H_{4}\right.$ and $\left.H_{7}\right)$ are rejected as the values of $T$ statistics are less than 1.65 and $P$ values are greater than 0.50 .
Table 3

Path Coefficient Analysis

\begin{tabular}{ccccc}
\hline Hypothesis & $\begin{array}{c}\text { Original } \\
\text { Sample }\end{array}$ & Std. Dev & $\begin{array}{c}\boldsymbol{T} \text { - } \\
\text { Statistics }\end{array}$ & P Values \\
\hline$H_{1}$ & 0.239 & 0.085 & 2.81 & 0.005 \\
$H_{2}$ & 0.233 & 0.071 & 3.30 & 0.001 \\
$H_{3}$ & 0.285 & 0.080 & 3.57 & 0.000 \\
$H_{4}$ & 0.045 & 0.111 & 0.40 & 0.686 \\
$H_{5}$ & 0.215 & 0.100 & 2.14 & 0.033 \\
$H_{6}$ & 0.248 & 0.118 & 2.09 & 0.036 \\
$H_{7}$ & 0.159 & 0.147 & 1.08 & 0.280 \\
\hline
\end{tabular}

\section{Discussions}

The first hypothesis stating that reach has a positive effect on brand awareness is supported. The highest mean of reach indicates that SMIs pay special attention to their audiences or followers by providing reviews/ endorsements about restaurants and cafes in Surabaya. This is also aligned with the results of cross loading that most reflecting reach attributes of SMIs. Usually, SMIs share stories or feeds and provide reviews about the restaurants and cafes intensively via Instagram. As a result, consumers become aware of the restaurants or cafes' brands promoted by SMIs.

This result is in accordance with a study conducted by Booth and Matic (2011) who find the strengths of SMIs that can shape brand awareness. It is also in line with the result of Purwaningwulan et al. (2018) which show that reach has a positive and significant impact on brand awareness of HIJUP products.

The second hypothesis mentioning that relevance has a positive and significant effect on brand awareness is supported. Mean of relevance indicates that SMIs have special competence and expertise in endorsing the restaurants and cafes in Surabaya. Then, loading factors of relevance also show that among SMIs and consumers have similar interests.

The similarities among SMIs and consumers can increase brand awareness of the restaurants and cafes in Surabaya. So, when consumers are asked to mention the first brand coming up from their minds, they can name it quite well. This is also in line with the results of the studies by Booth and Matic (2011); Purwaningwulan et al. (2018).

The third hypothesis saying that resonance has a positive and significant effect on brand awareness is supported. The values of mean and loading factors have shown that SMIs reviews or endorsements about restaurants and cafes in Instagram can make consumers view them and like or even give comments. Besides that, the reviews can sustain for a long time.

These sustainable reviews will be in the consumer minds so that it enables consumers to 
remember and name the brands later on. Even, consumers can also share the reviews to others. Thus, it can increase brand awareness of the restaurants and cafes in Surabaya in the consusmer minds. This is also in accordance with studies by Booth and Matic (2011), Purwaningwulan et al. (2018).

Studies by Sudha and Shenna (2017) as well as Cooley and Parks-Yancy (2019) show that reach has has a positive and significant effect on purchasing decision. In contrast, in this study, reach has a positive but insignificant impact on purchase decision. So, the fourth hypothesis is rejected.

This contrast can be explained from the fact of SMI popularity which is indicated by the greater number of followers. Generation Z, who are familiar and sensitive with social media like Instagram, understand well with the facts of fake followers and fake accounts transactions in Instagram. Therefore, the level of popularity shown from the greater number of followers cannot justify consumer trust and decision to purchase restaurants and cafes' products or services promoted by SMI.

In addition, some of the reviews may be too excessive. Sometimes the visual video about the products or services of the restaurants and cafes do not taste as expected; it can be too hot or sweet for certain consumers. That is why reach has a positive but insignificant impact on purchase decision

Then, the fifth hypothesis mentioning that relevance has a positive and significant effect on purchasing decision is supported. The highest loading factor of relevance indicates that consumers trust SMIs for their ability and strength. So, consumers tend to like and sometimes comment on SMIs' reviews on Instagram. Thus, it can affect consumer purchase decisions. The result is in line with studies by Cooley and ParksYancy (2019); Sudha and Shena (2017).

Furthermore, the sixth hypothesis saying that resonance has a positive and significant influence on purchasing decision is supported. The cross-loading value representing relevance is the fact that SMIs' reviews can last longer on Instagram so that consumers have more chances to like them. Therefore, it may influence consumer purchase decision. It happens because Generation $\mathrm{Z}$ is easily influenced by the hype of social media. So, they will buy cafes and restaurants' products or services when these products or services are interesting or booming. This is also in accordance with studies by Cooley and Parks-Yancy (2019); Sudha and Shena (2017).

Finally, the seventh hypothesis saying that brand awareness has a positive and significant influence on purchasing decision is rejected. Eventhough consumers have brand awareness of the restaurants or cafes promoted by SMIs, consumers do not always have purchase decision signifantly. This can happen due to some reasons. One of them is the fact that consumers do not have strong brand awareness that can influence them to purchase the products or services promoted by SMIs. Apart from that, there could be some other factors that are not analyzed in this study as the value of $R^{2}$ is very weak.

\section{Conclusions}

SMIs dimensions of reach, relevance and resonance can influence brand awareness of restaurants and cafes in Surabaya towards Generation Z positively and significantly. The two dimensions, relevance and resonance, also influence consumer purchase decisions of restaurants and cafes in Surabaya positively and significantly; while, reach influence purchase decision positively but insignificantly. Generation $\mathrm{Z}$ is aware of the fact of fake followers who are paid to follow certain account in Instagram. So, it cannot make Generation Z justify their purchase decisions. Moreover, brand awareness of restaurants and cafes in Surabaya has positive but insignificant impact on purchase decision of Generation $\mathrm{Z}$.

\section{Recommendations}

As five of the seven hypotheses are supported, it is recommended that restaurants and cafes' managers employ SMIs. But the managers must be very careful in selecting SMIs, especially from the dimensions of relevance and resonance, to endorse the products and services of their restaurants and cafes. This is because these two dimensions influence more on brand awareness and purchase decision than reach dimension. By having SMIs who have expertise about food and beverages, it can build consumer trust to purchase the restaurants and cafes' products or services.

For SMIs themselves, it would be better if they can focus to improve their expertise by providing reviews that are not too exaggerated, but natural and trustable. Thus, it may improve consumers brand awareness that can also lead to their purchase decisions of restaurants and cafes' products or services. Besides that, SMIs can also give a giveaway to build consumer engagement on SMIs' Instagram contents or account.

This study can be used as a reference for further research on SMIs. It would be better to examine other generations such as the Alpha generation and others who have promising purchasing power in the future. This research can also be developed to assess SMIs 
from other social media platforms such as Youtube or Tik Tok which are developing rapidly in 2020. Other variables from brand equity, such as brand image, brand association, perceived quality, and brand loyalty, can also be studied. In addition, it is advisable to have more samples and distribute offline questionnaires to get more reliable results.

\section{References}

Booth, N., \& Matic, J. A. (2011). Mapping and leveraging influencers in social media to shape corporate brand perceptions. Corporate Communications: An International Journal, 16(3), 184 191.

Brown, D., \& Hayes, N. (2008). Influencer marketing. USA: Routledge.

Cooley, D., \& Parks-Yancy, R. (2019). The effect of social media on perceived information credibility and decision making. Journal of Internet Commerce, 18(3), 249-269.

Devi, S. (2018, Agustus 28). Mutualisme? Strategi "endorsement" oleh suatu perusahaan. Kompasiana.com Retrieved from https://www.kompa siana.com/divvv/5b849ab3ab12ae46335c7cd7/ mutualisme-strategi-endorsement-oleh-suatu-per usahaan?page $=$ all.

Glucksman, M. (2017). The rise of social media influencer marketing on lifestyle branding: A case study of lucie fink. Elon Journal of Undergraduate Research in Communications, 8(2), 77-87. Retrieved from https://www.elon.edu/u/academic s/communications/journal/wp-content/uploads/sit es/153/2017/12/Fall2017Journal.pdf\#page=77.

Gorry, G. A., \& Westbrook, R. A. (2009). Winning the internet confidence game. Corporate Reputation Review, 12(3), 195-203. doi: 10.1057/crr.2009. 16.

Guruge, M. C. B. (2018). Comparison between attributes related to celebrity endorsement and social media influencer marketing: A conceptual review. Sri Lanka Journal of Marketing, 4, 17-37.

Habibi, M. (2014). Pengaruh dimensi gaya hidup terhadap keputusan pembelian smartphone Blackberry di Purworejo. SEGMEN Jurnal Manajemen dan Bisnis, 10(1.a), 1-10.

Hariyanti, N. T., \& Wirapraja, A. (2018). Pengaruh influencer marketing sebagai strategi pemasaran digital era moderen (Sebuah studi literatur). Eksekutif, 15(1), 133-146.

Kotler, P., \& Keller, K. L. (2016). Marketing management (15th global ed.). England, UK: Pearson.
Kunto, Y. S., \& Agusli, D. (2013). Analisa pengaruh dimensi ekuitas merek terhadap minat beli konsumen Midtown Hotel Surabaya. Jurnal Strategi Pemasaran, 1(2), 1-8.

Lukman, M. D. (2014). Analisis pengaruh ekuitas merek terhadap keputusan pembelian dan kepuasan konsumen produk teh botol Sosro kemasan kotak. Jurnal Administrasi Bisnis, 10(1), 64-81.

Owyang, J., Jones, A., Tran, C., \& Nguyen, A. (2011). Social business readiness: How advanced companies prepare internally. San Mateo, United States: Altimeter Group.

Peter, J. P., \& Olson, J. C. (2014). Perilaku konsumen dan strategi pemasaran. Jakarta: Salemba Empat.

Purwaningwulan, M. M., Suryana, A., Wahyudin, U., \& Dida, S. S. (2018). The uniqueness of influencer marketing in the Indonesian muslim fashion industry on digital marketing communication era. Proceeding of International Conference on Business, Economic, Social Sciences and Humanities (ICOBEST 2018), pp. 114-119. Retrieved from https:// dx.doi.org/10.2991/icobest-18.2 018.26.

Rangkuty, F. (2004). Analisis SWOT teknik membedah kasus bisnis. Jakarta: PT Gramedia Pustaka Utama.

Renaldo, N., Sudarno, S., \& Marice, H. (2020). The improvement of Generation $Z$ financial wellbeing in Pekanbaru, Indonesia. Jurnal Manajemen dan Kewirausahaan, 22(2), 142-151. https://doi.org/10.9744/jmk.22.2.142-1 51

Rossiter, J. R., Percy, L., \& Bergkvist, L. (2018). Marketing communications: Objectives, strategy, tactics. London: SAGE Publications.

Royan, F. M. (2004). Marketing selebrities. Jakarta: Elex media komputindo.

Sampurno, N. V., Ciakrawinata, C. P., \& Jokom, R. (2019). Pengaruh karakteristik selebriti endorser terhadap minat beli melalui kesadaran merek hotel di Instagram. Jurnal Manajemen Perhotelan, 5(1), 36-44.

Sharon, F.Wijaya, S., \& Iskandar, V. (2018). Pengaruh karakteristik celebrity endorser melalui media sosial Instagram terhadap minat beli konsumen pada restoran dan cafe di Surabaya. Jurnal Hospitality dan Manajemen Jasa, 6(2), 390-404.

Shimp, T. A., Wood, S. L., \& Smarandescu, L. (2007). Self-generated advertisements: Testimonials and the perils of consumer exaggeration. Journal of Advertising Research, 47(4), 453-461.

Soebianto, 2014. Analisis pengaruh faktor-faktor brand equity sepeda motor merek Honda terhadap keputusan pembelian pada konsumen di kota Bandung. E-Journal Graduate Unpar, 1(1), 14-37. 
Solis, B. \& Webber, A. (2012). The rise of digital influence: A "how-to" guide for businesses to spark desirable effects and outcomes through social media influence. USA: Altimeter Group.

Sudha, M., \& Sheena, K. (2017). Impact of influencers in consumer decision process: the fashion industry. SCMS Journal of Indian Management, 14(3), 14-30.

Suryani, F. L. (2015). Instagram dan fashion remaja (Studi kasus peran media sosial instagram ter- hadap trend fashion remaja dalam akun @OOT DINDO tahun 2014). Retrieved Maret, 2020 from http://eprints.uns.ac. id/19490/

U Rianse, A. (2012). Metodologi penelitian sosial dan ekonomi teori dan aplikasi. Bandung: Alfabeta.

Yang, Y. T., Chi, H., \& Yeh, H.R. (2009). The impact of brand awareness on consumer purchase intention: Themediating effect of perceived quality dan brand loyalty. The Journal of Internasional Management Studies, 4(1), 135-144. 